\title{
Granular Size Effect of Clinoptilolite on Maize Seedlings Growth
}

\author{
Alessandra Trinchera*, Carlos Mario Rivera, Simona Rinaldi, Anna Salerno, Elvira Rea and \\ Paolo Sequi
}

Agricultural Research Council-Research centre for the plant-soil system, Via della Navicella, 2-4 00184 Rome (Italy)

\begin{abstract}
Clinoptilolite has been successfully used in growing media for containerized horticultural and floricultural production. However, limited data exist on the effects and interaction between particle size and organic nutrient enrichment of the clinoptilolite. One granular $(1-3 \mathrm{~mm})$ and micronized $(<30 \mu \mathrm{m})$ clinoptilolite was added to quartz sand, an inert growing substrate, at two doses $(0.1 \%$ and $3 \% \mathrm{v} / \mathrm{v})$, without or with addition of wine vinasse as nutrient source at four concentrations $\left(0 \mathrm{mg}_{\mathrm{F}} \times \mathrm{L}_{\text {subst }}{ }^{-1}, 10 \mathrm{mg}_{\mathrm{F}} \times \mathrm{L}_{\text {subst }}{ }^{-1}, 100 \mathrm{mg}_{\mathrm{F}} \times \mathrm{L}_{\text {subst }}{ }^{-1}\right.$ and $\left.1000 \mathrm{mg}_{\mathrm{F}} \times \mathrm{L}_{\text {subst }}{ }^{-1}\right)$ to evaluate their effect on root growth for five days or the appearance of the second true leaf.

Root mucigel was produced in zones where clinoptilolite particles adhered to the root surface. Microscopic analysis of isolated roots showed the increase of secondary roots and the proliferation of root hairs in maize treated with both micronized and granular clinoptilolite, with the contemporary production of root mucigel in zones where zeolite particles adhered to the root surface. It is hypothesized that the enhanced production of mucigel by root cells can favour not only the penetration of roots into the inert substrate, but also the solubilization of organic matter and nutrient availability, in particular when micronized clinoptilolite was present in the growing medium. Therefore, micronized clinoptilolite behaved as a sort of a "physical stimulant" for roots during seedlings, promoting, as a consequence, maize shoot development. Effectively, the highest increase in shoot growth was observed at the highest dose $(3 \% \mathrm{v} / \mathrm{v})$ of micronized zeolite, with the optimal rate of organic fertilizer $\left(100 \mathrm{mg}_{\mathrm{F}} \times \mathrm{L}_{\text {subst }}{ }^{-1}\right)$.
\end{abstract}

Keywords: Clinoptilolite, maize, mucigel, organic fertilizer, root, wine vinasse.

\section{INTRODUCTION}

Different zeolites or clinoptilolites (chabazite, natrolite, phillipsite, clinoptilolite, etc.) are present in nature and characterised by a very complex three-dimensional structure, with a high specific surface [1], defined as a "openstructure", and a high cation exchange capacity. The internal cavities of zeolites and, in particular, clinoptilolite for sterical reasons [2], can host calcium, magnesium, sodium ions, exchangeable with ammonium or potassium.

Zeolites are good absorbents, due to the elevate electrical charge of their mineral alumino-silicate surface they can behave as "molecular sieves" [3, 4]. For this reason, they have been used in water purification [5], as catalysts in petrochemical industry, or $\mathrm{O}_{2}$ generators in medicine and applied in agriculture [6].

Particularly, clinoptilolite has been used as fertiliser, being a source of potassium [7] and a nitrogen slow-release compounds, if previously treated with ammonium ions [8] [9-11].

The influence of clinoptilolite on soil properties and humic matter characteristics was deeply studied by Filcheva

*Address correspondence to this author at the Agricultural Research Council - Research centre for the plant-soil system, C.R.A. - R.P.S. Via della Navicella, 2-4, 00184 Rome, Italy; Tel: +39-06-77078141;

Fax: +39-06-7005711; E-mail: alessandra.trinchera@entecra.it and Tsadilas [12], who verified that clinoptilolite increases soil $\mathrm{pH}$ and exchangeable potassium. Clinoptilolites can be also utilised as plant growing medium [13], when added or coated with mineral fertilizers and/or selected micronutrients $[14,15]$. Recently, zeoponic substrates made by Kexchanged clinoptilolite are under development for use in advanced life support system testbeds and microgravity experiments [16].

The zeolite has already been used as soil amendment with satisfactory results $[17,18]$, but also as component of growing media in containerized seedlings propagation [19, 20]: however, data are not still available on the effect of clinoptilolite particles' size and doses as growing media component, particularly in relation to the co-addition with different organic materials.

The scope of this research was to evaluate the effect of clinoptilolite on maize seedlings, when added to the growing medium at different granular size and rates, using an organic fertilizer as potential nutrient source. The association between clinoptilolite and organic fertiliser was chosen in order to evidence eventual synergic effect on maize seedlings, yet at the early stage of growth, also taking into account the related mechanism of action. Maize was chosen as reference plant species, being its primary root easily isolable and valuable in terms of calliper, weight and length. Particular attention was focused on the effect of different clinoptilolite granulometry on maize root morphology, to evaluate its performance when used as growing media component. 


\section{MATERIALS AND METHODOLOGY}

Plant material and growing system - Maize seeds (Zea mays L., cv. Suarta) were completely imbibed for $24 \mathrm{~h}$ with distilled water, sterilised with $\mathrm{NaClO} 5 \%$, washed with distilled water and then allowed to germinate in sterile opencontainers $(60 \mathrm{~cm} \times 40 \mathrm{~cm})$, containing $200 \mathrm{~mL}$ of $0.5 \mathrm{mM}$ $\mathrm{CaSO}_{4}$. The containers were covered with drilled aluminium sheets and incubated in a growth chamber at $28^{\circ} \mathrm{C}$ and $70 \%$ relative humidity.

After $72 \mathrm{~h}$, seedlings with $2.5 \pm 0.5 \mathrm{~cm}$ of radicle length were transplanted in individual little pots (volume: $120 \mathrm{~mL}$, maximum diameter: $7 \mathrm{~cm}$ ) containing powdered quartz sand added with clinoptilolite, treated with different rates of an organic fertilizer, and were grown for 5 days before harvest for root analysis.

The utilised clinoptilolite has the following characteristics: $64.3 \% \mathrm{SiO}, 13.7 \% \mathrm{Al}_{2} \mathrm{O}_{3}, 5.0 \% \mathrm{CaO}, 3.4 \% \mathrm{H}_{2} \mathrm{O}, 2.7 \%$ $\mathrm{Fe}_{2} \mathrm{O}_{3}, 2.2 \% \mathrm{Na}_{2} \mathrm{O}, 1.2 \% \mathrm{MgO}, 1.4 \% \mathrm{~K}_{2} \mathrm{O}, 0.8 \% \mathrm{FeO}, 0.4 \%$ $\mathrm{TiO}_{2}, 0.1 \% \mathrm{P}_{2} \mathrm{O}_{5}$. Specific cation exchange capacity was $120-150 \mathrm{meq} \times 100 \mathrm{~g}^{-1}$ for $\mathrm{NH}_{4}{ }^{+}, 7 \mathrm{meq} \times 100 \mathrm{~g}^{-1}$ for $\mathrm{Mg}^{2+}, 95$ meq $\times 100 \mathrm{~g}^{-1}$ for $\mathrm{Ca}^{2+}, 25 \mathrm{meq} \times 100 \mathrm{~g}^{-1}$ for $\mathrm{Na}^{+}$and 23 meq $\times 100 \mathrm{~g}^{-1}$ for $\mathrm{K}^{+}$. Other chemical-physical properties were: melting point $1300^{\circ} \mathrm{C}$, IEC $1.2-1.5$ meq $\times \mathrm{g}^{-1}$, water moisture $10 \%$, CEC $120-130 \mathrm{meq} \times 100 \mathrm{~g}^{-1}, \mathrm{pH} 7.6$.

The organic fertilizer, termed "Organic $\mathrm{N}$ fertilizer" in the Annex 1 of the Italian law (D.L. n. 217, 29/04/2006), was dried wine vinasse ( $28 \%$ of total organic C, $3 \%$ of total $\mathrm{N}$ ), produced by Distillerie Bonollo S.p.A. (Italy).

The following treatments were carried out on clinoptilolite in granular (G: $\varnothing=1-3 \mathrm{~mm}$ ) and micronized (M: $\varnothing<30 \mu \mathrm{m})$ form, applied with two concentrations (dose 1: $0,1 \% \mathrm{v} / \mathrm{v}$; dose $2: 3 \% \mathrm{v} / \mathrm{v}$ ), without or with solid organic fertilizer $(\mathrm{F})$ added with different concentrations (0 $\mathrm{mg}_{\mathrm{F}} \times \mathrm{L}_{\text {subst }}{ }^{-1}$ as control, $10 \mathrm{mg}_{\mathrm{F}} \times \mathrm{L}_{\text {subst }}{ }^{-1}, 100 \mathrm{mg}_{\mathrm{F}} \times \mathrm{L}_{\text {subst }}{ }^{-1}$ and $1000 \mathrm{mg}_{\mathrm{F}} \times \mathrm{L}_{\text {subst }}{ }^{-1}$ ).

The experimental plan has a combined and factorial scheme: $[4+1$ (control) clinoptilolite treatments $] \times[3+1$ (control) fertilizer doses] $\times 6$ replications $(3$ pots per treatment; two seeds per pot $=6$ plants per treatment). The overall number of plots was 60 (Table $\mathbf{1}$ ).

Table 1 Experimental plan (each treatment was performed on six plants).

The trial was carried out in a growth chamber at $28^{\circ} \mathrm{C}$ and $70 \%$ relative humidity. Seedlings were subirrigated through saturation of pot bottom zone by saucers filled with distilled water $\left(150 \mathrm{~mL}_{\mathrm{water}} \times \operatorname{pot}^{-1}\right)$, daily replacing it. After 5 days from pot transplantation, corresponding to the second true leaf growth [21, 22], plantlets were harvested for measurements.

Measurements - At the beginning of the trial, plantlets' primary root initial length $\left(\mathrm{R}_{\mathrm{i}}\right.$, in $\left.\mathrm{cm}\right)$ was measured.

On day 5 , roots were washed twice with distilled water in order to eliminate particles of quartz sand. Then, primary root final length $\left(\mathrm{R}_{\mathrm{f}}\right.$, in $\left.\mathrm{cm}\right)$, primary root weight $(\mathrm{RW}$, in $\mathrm{g})$, shoot length (SL, in $\mathrm{cm}$ ) and shoot weight $(\mathrm{SW}$, in $\mathrm{g}$ ) were assessed for each seedling.

Being interested to interactions among different granular size clinoptilolites and maize root surface in absence or presence of the organic fertilizer, root morphology was examined, before and after washing roots, through digital acquiring of microscopic images, using a digital camera (Nikon Coolpix 8400) linked to an optical stereo-microscope (Nikon SMZ-U).

Statistical analysis - All data were statistically analysed by two-way ANOVA. Duncan's multiple range test was performed at $\mathrm{P}=0.05$ measured on each of the significant variables.

\section{RESULTS}

\section{3a. Root growth characteristics}

Table 2 reports the root elongation values $(\Delta R)$, which are calculated by $\mathrm{R}_{\mathrm{f}^{-}}-\mathrm{R}_{\mathrm{i}}$.

The addition of wine vinasse did not affect $\Delta \mathrm{R}(\mathrm{P}=0.19)$ and no significant interactive effects were observed in relation to contemporary addition of clinoptilolite and organic fertilizer $(\mathrm{P}=0.31)$. On the contrary, both the granular and the micronized clinoptilolite induced a highly significant increase of root elongation $(\mathrm{P}=0.00009)$.

In particular, the highest values were obtained in treatments with granular clinoptilolite at the lowest dose (G1) and with micronized one at both the doses (M1 and M2), while the lowest value was obtained when granular clinoptilolite was added at the highest dose (G2).

Primary root weight $(\mathrm{RW})$ was strongly affected $(\mathrm{P}=$ 0.003 ) by interaction with clinoptilolite and organic fertilisation (Table 3).

Table 1. Experimental Plan (Each Treatment was Performed in Three Replicates, Two Seeds Per Pot)

\begin{tabular}{|c|c|c|c|c|}
\hline & $\begin{array}{c}\text { Dried Wine } \\
\text { Vinasse } \\
\left(0 \mathrm{mg}_{\mathrm{F}} \times \mathrm{L}^{-1}\right)\end{array}$ & $\begin{array}{c}\text { Dried Wine } \\
\text { Vinasse } \\
\left(10 \mathrm{mg}_{\mathrm{F}} \times \mathrm{L}^{-1}\right)\end{array}$ & $\begin{array}{c}\text { Dried Wine } \\
\text { Vinasse } \\
\left(100 \mathrm{mg}_{\mathrm{F}} \times \mathrm{L}^{-1}\right)\end{array}$ & $\begin{array}{c}\text { Dried Wine } \\
\text { Vinasse } \\
\left(1000 \mathrm{mg}_{\mathrm{F}} \times \mathrm{L}^{-1}\right)\end{array}$ \\
\hline Zeolite $(0 \mathrm{mg})$ & Control & F10 & F100 & F1000 \\
\hline Micronized zeolite $(0,1 \%$-dose 1$)$ & M1 & M1-F10 & M1-F100 & M1-F1000 \\
\hline Granular zeolite $(0,1 \%$ - dose 1$)$ & G1 & G1-F10 & G1-F100 & G1-F1000 \\
\hline Granular zeolite (3\% - dose 2$)$ & $\mathrm{G} 2$ & G2-F10 & G2-F100 & G2-F1000 \\
\hline
\end{tabular}


It was significantly higher at $100 \mathrm{mg} \times \mathrm{L}^{-1}$ of organic fertilizer for all zeolite treatments, with the exception of granular clinoptilolite at highest dose $(\mathrm{G} 2,3 \% \mathrm{v} / \mathrm{v})$. With $0.1 \%$ $\mathrm{v} / \mathrm{v}-\mathrm{G} 1$ granular clinoptilolite the highest values of RW were obtained with or without wine vinasse, whereas with $0.1 \% \mathrm{v} / \mathrm{v}-\mathrm{M} 1$ micronized clinoptilolite the highest value was obtained with $100 \mathrm{mg}^{-1}$ wine vinasse. This latter treatment gave the highest RW value, being $62 \%$ higher with respect the RW of the control.

Since primary root weight and root elongation are related, it was investigated the combined effect of clinoptilolite and organic fertilizers on root weight/length ratio (data not shown). Generally, primary root maintained a quite constant weight/length ratio $\left(\sim 18 \mathrm{mg} \times \mathrm{cm}^{-1}\right)$, with the lowest values in the control and G2 with 0,10 and $100 \mathrm{mg}_{\mathrm{F}} \times \mathrm{L}^{-1}$ fertilizer $\left(\sim 14 \mathrm{mg} \times \mathrm{cm}^{-1}\right)$ and the highest one in M1 with $100 \mathrm{mg}_{\mathrm{F}} \times \mathrm{L}^{-1}$ fertilizer $\left(\sim 24 \mathrm{mg} \times \mathrm{cm}^{-1}\right)$.

Ipogeic portion of maize, treated with both the granular and the micronized clinoptilolite at the lowest dose, in presence of organic fertilizer, showed a more complex root apparatus: in particular, since at first stage of root growth, the primary roots of G1-F100 and M1-F100 were characterized by the presence of root hairs, not present in the primary root of untreated control (Fig. 1).

\section{3b. Shoot growth characteristics}

In our experimental scheme, no interaction between "clinoptilolite" and "organic fertilizer" factors was observed ( $\mathrm{P}$ $=0.16)$ in relation to shoot length (SL), whereas both the clinoptilolite and the organic fertilizer addition influenced it

Table 2. Root Elongation $(\Delta \mathbf{R})$ of Zea Mays L. in Relation to the Addition of Clinoptilolite and Organic Fertilizer (Average Values \pm Standard Deviation)

\begin{tabular}{|c|c|c|c|}
\hline Treatment & $\begin{array}{c}\text { Clinoptilolite Dose } \\
(\% \mathrm{v} / \mathrm{v})\end{array}$ & Organic Fertilizer Rate $\left(\mathbf{m g}_{\mathrm{F}} \times \mathbf{L}^{-1}\right)$ & $\begin{array}{l}(\Delta \mathbf{R}) \\
(\mathbf{c m})\end{array}$ \\
\hline Control & 0 & 0 & $8.7 \pm 2.7 \mathrm{abc}$ \\
\hline F10 & 0 & 10 & $7.2 \pm 2.7 \mathrm{ab}$ \\
\hline F100 & 0 & 100 & $9.0 \pm 3.9 \mathrm{~b}$ \\
\hline F1000 & 0 & 1000 & $8.1 \pm 2.0 \mathrm{ab}$ \\
\hline M1 & 0.1 & 0 & $9.4 \pm 2.9 \mathrm{bc}$ \\
\hline M1-F10 & 0.1 & 10 & $9.1 \pm 2.5 \mathrm{bc}$ \\
\hline M1-F100 & 0.1 & 100 & $11.4 \pm 2.9 \mathrm{~cd}$ \\
\hline M1-F1000 & 0.1 & 1000 & $7.6 \pm 3.5 \mathrm{abc}$ \\
\hline M2 & 3 & 0 & $7.5 \pm 2.3 \mathrm{abc}$ \\
\hline M2-F10 & 3 & 10 & $10.2 \pm 2.5 \mathrm{bc}$ \\
\hline M2-F100 & 3 & 100 & $9.9 \pm 2.3 \mathrm{bc}$ \\
\hline M2-F1000 & 3 & 1000 & $8.2 \pm 3.3 \mathrm{abc}$ \\
\hline G1 & 0.1 & 0 & $8.8 \pm 2.7 \mathrm{abc}$ \\
\hline G1-F10 & 0.1 & 10 & $11.0 \pm 2.8 \mathrm{~cd}$ \\
\hline G1-F100 & 0.1 & 100 & $11.8 \pm 1.7 \mathrm{~cd}$ \\
\hline G1-F1000 & 0.1 & 1000 & $9.8 \pm 2.4 \mathrm{bc}$ \\
\hline G2 & 3 & 0 & $6.7 \pm 2.3 \mathrm{a}$ \\
\hline G2-F10 & 3 & 10 & $5.7 \pm 3.9 \mathrm{a}$ \\
\hline G2-F100 & 3 & 100 & $6.2 \pm 4.0 \mathrm{a}$ \\
\hline G2-F1000 & 3 & 1000 & $8.1 \pm 1.8 \mathrm{ab}$ \\
\hline
\end{tabular}

\begin{tabular}{|c|c|c|c|}
\hline & Clinoptilolite dose & Organic fertilizer rate & $\begin{array}{c}\text { Clinoptilolite dose } \times \text { organic fertil- } \\
\text { izer rate }\end{array}$ \\
\hline Significance & $* * *$ & $\mathrm{NS}$ & $\mathrm{NS}$ \\
\hline
\end{tabular}

NS : not significant differences; $* * *$ significant differences at $\mathrm{P}<0.005$. 
Table 3. Primary Root Weight (RW) of Zea Mays L. in Relation to the Addition of Clinoptilolite and Organic Fertilizer (Average Values \pm Standard Deviation; Significant Differences for $\mathbf{P}<0.05$ )

\begin{tabular}{|c|c|c|c|}
\hline Treatment & $\begin{array}{c}\text { Clinoptilolite Dose } \\
(\% \mathrm{v} / \mathrm{v})\end{array}$ & $\begin{array}{l}\text { Organic Fertilizer Rate } \\
\qquad\left(\mathbf{m g}_{\mathrm{F}} \times \mathbf{L}^{-1}\right)\end{array}$ & $\begin{array}{r}\text { RW } \\
(\mathrm{g})\end{array}$ \\
\hline Control & 0 & 0 & $0.13 \pm 0.02 \mathrm{ab}$ \\
\hline F10 & 0 & 10 & $0.15 \pm 0.04 \mathrm{abc}$ \\
\hline F100 & 0 & 100 & $0.19 \pm 0.06 \mathrm{def}$ \\
\hline M1 & 0.1 & 0 & $0.13 \pm 0.03 \mathrm{ab}$ \\
\hline M1-F10 & 0.1 & 10 & $0.13 \pm 0.01 \mathrm{ab}$ \\
\hline M1-F100 & 0.1 & 100 & $0.21 \pm 0.03 \mathrm{f}$ \\
\hline M2-F100 & 3 & 100 & $0.20 \pm 0.07 \mathrm{def}$ \\
\hline M2-F1000 & 3 & 1000 & $0.16 \pm 0.04$ bcde \\
\hline G1 & 0.1 & 0 & $0.20 \pm 0.04$ ef \\
\hline G1-F10 & 0.1 & 10 & $0.18 \pm 0.03 \mathrm{cdef}$ \\
\hline G1-F100 & 0.1 & 100 & $0.20 \pm 0.04 \mathrm{def}$ \\
\hline G1-F1000 & 0.1 & 1000 & $0.19 \pm 0.05 \mathrm{def}$ \\
\hline $\mathrm{G} 2$ & 3 & 0 & $0.11 \pm 0.03 \mathrm{a}$ \\
\hline
\end{tabular}

\begin{tabular}{|c|c|c|c|}
\hline & Clinoptilolite dose & Organic fertilizer rate & $\begin{array}{c}\text { Clinoptilolite dose } \times \text { organic fertil- } \\
\text { izer rate }\end{array}$ \\
\hline Significance & NS & NS & $* *$ \\
\hline
\end{tabular}

NS : not significant differences; **significant differences at $\mathrm{P}<0.01$;

significantly $(\mathrm{P}=0.0008$ and $\mathrm{P}=0.023$, respectively). In Fig. (2), on the left, average values obtained for all the treatments in relation to the factor "clinoptilolite" while, on the right, average values obtained for all the treatments in relation to the factor "organic fertilizer" are reported, respectively.

The micronized clinoptilolite at the highest dose (M2) strongly increased SL as well as, at a lower extent, the granulate type with the same dose, for all the wine vinasse rates.

Among the different concentrations of the organic fertilizer, only the highest one (F-1000) was effective on SL, while the other ones had no effect on this parameter, for all clinoptilolite treatments: probably, this result was obtained by the higher "fertilization" effect due to the highest rate of wine vinasse, being the organic fertilizer the unique added source of nutrient into the pot system.

Also in the case of shoot weight (SW), there was not interactive effect between clinoptilolite and wine vinasse application $(\mathrm{P}=0.32)$, while clinoptilolite addition $(\mathrm{P}=0.021)$ and organic fertilization $(\mathrm{P}=0.0007)$ significantly influenced SW (Fig. 2). The weight/length shoot ratio was not influenced by the considered factors.

\section{3c. Microscopic observations}

In order to better understand the influence of the two types of zeolites on root apparatus, a study on the effect on root morphology at microscopic scale was carried out. 


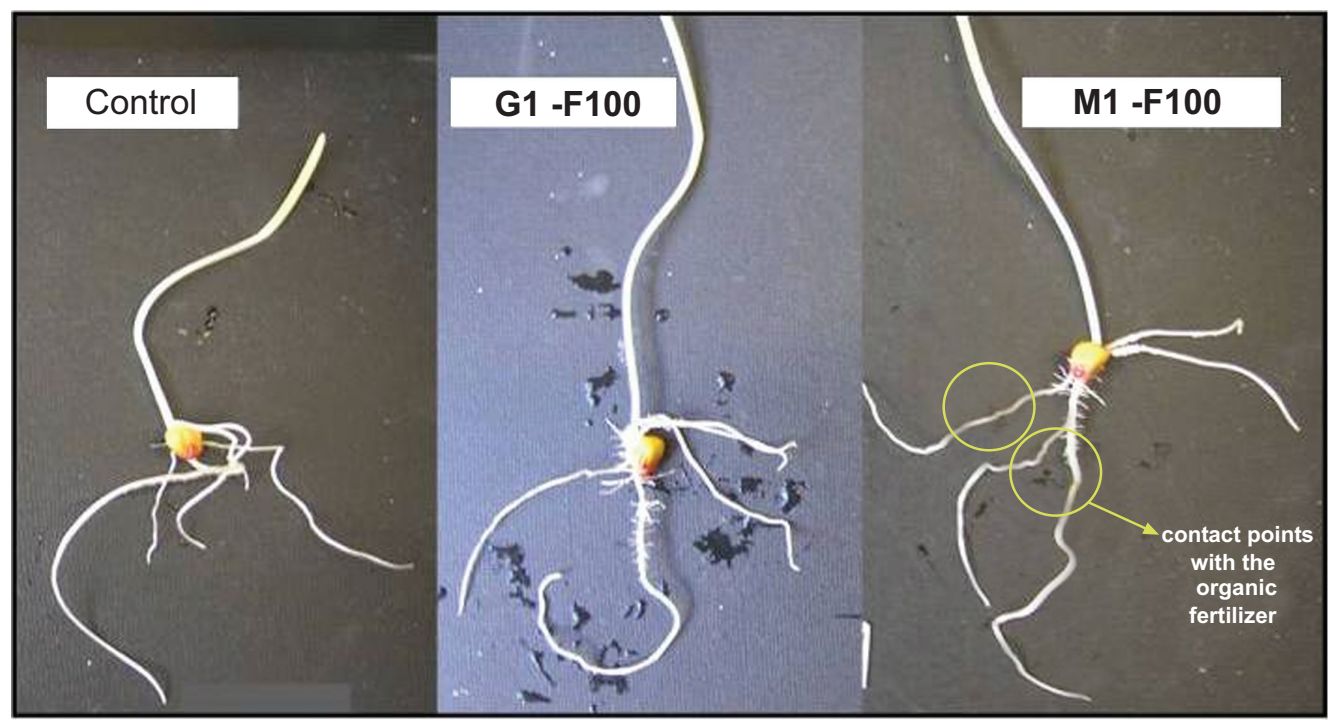

Fig. (1). Effect of different growing media on Zea mays L. roots: control (inert quartz sand), G1-F100 (granular clinoptilolite at $0.1 \%$ v/v +

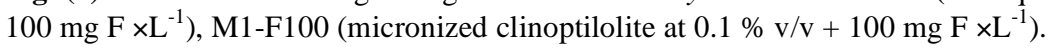
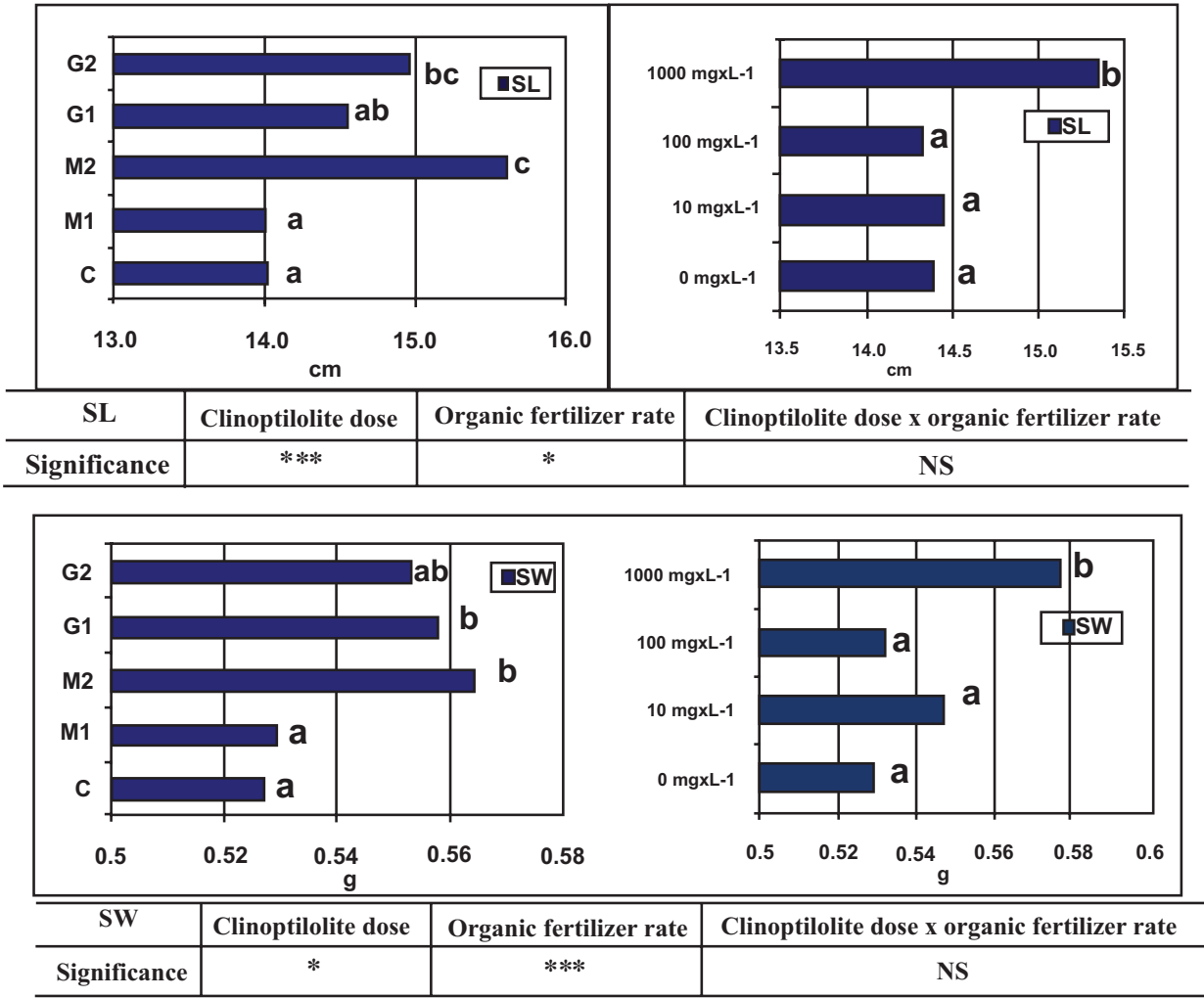

NS : not significant differences; ${ }^{*}$ : significant differences at $\mathrm{P}<0.05$; $^{*}$ : significant differences at $\mathrm{P}<0.01$;

*** : significant differences at $\mathbf{P}<\mathbf{0 . 0 0 5}$

Fig. (2). Effect of factor "clinoptilolite" (G1, G2, M1 and M2) and factor "organic fertilizer" (1000, 100, 10 and $\left.0 \mathrm{mg} \times \mathrm{L}^{-1}\right)$ on shoot length (SL) and weight (SW). "C" is related to all the treatments with or without fertilizer addition, but without clinoptilolite; " $0 \mathrm{mg} \times \mathrm{L}^{-1, "}$ is related to all the treatments with or without clinoptilolite, but without fertilizer addition. Different letters denote significant differences at $\mathrm{P}<0.05$.

After washing twice, through immersion in distilled water, the roots treated with $0.1 \% \mathrm{v} / \mathrm{v}$ micronized clinoptilolite and $100 \mathrm{mg}_{\mathrm{F}} \times \mathrm{L}^{-1}$ of wine vinasse (M1-F100), the quartz sand and the powdered clinoptilolite remained on the roots surface, probably because of the glue-effect by root-produced mucigel, as clearly shown in Fig. (3-A). The organic fertilizer added to the substrate was partially dissolved in the mucigel drops, which appeared brown-coloured, while in the case of roots grown without clinoptilolite (F100), mucigel was quite absent on the root surface and the organic fertiliser remained on the root surface and seemed to be not solubilised by water (Fig. 3-B). Moreover, clinoptilolite promoted the formation of little adventitious roots (Fig. 3-A), whereas these roots were not present when seedlings were grown without micronized zeolite (Fig. 3-B). Otherwise, the microscopic analysis of an intact root treated with the granular 
clinoptilolite at $0.1 \% \mathrm{v} / \mathrm{v}$ (G1) showed, before washing, a root hairs proliferation in root zones close to granules of clinoptilolite (Fig. 4-A), together with the production of mucigel in correspondence of granules adhesion; the mucigel promoted the adhesion of zeolite on root surface (Fig. 4-B).

\section{DISCUSSION}

The starting hypothesis of our work was the positive effect played by clinoptilolite on maize seedlings in relation to its different granular size, explained by changes in root apparatus, as a consequence to physical contact of the zeolite with root surface.

On general terms, the effect of zeolite on root elongation has been already observed [17, 23], but the underlying mechanisms are poorly known.

Generally it is known that the effect of mechanical impedance on root morphology is determined by a severe reduction in root elongation rate and a corresponding increase in the diameter of impeded roots. Actually, the reduction of root system length was clearly detected by several authors, in particular by Veen and Boone [24] on maize. BoeufTremblay et al. [22] further verified that maize seedlings and plant growth were strongly influenced by mechanical impedance simulated by adding glass beads into the sterile growing media, producing roots shorter and heavier per unit of length.

In our work, the highest increase of weight/length ratio of maize primary root was obtained for treatment with micronized clinoptilolite at the lowest dose of $0.1 \%$, while a decrease was found for treatment with granular clinoptilolite, attesting the role of different clinoptilolite particles' size on root development.

Apparently, the lowest dose of micronized clinoptilolite acted by increasing both root elongation and weight/length ratio, that is producing roots heavier per unit of length. However, results obtained for root weight demonstrated that it was also strongly influenced by the interaction between clinoptilolite granular size and the organic fertilizer rate, the highest value obtained for micronized clinoptilolite at 100 $\mathrm{mg}_{\mathrm{F}} \times \mathrm{L}^{-1}$ substr. The action of clinoptilolite on root development
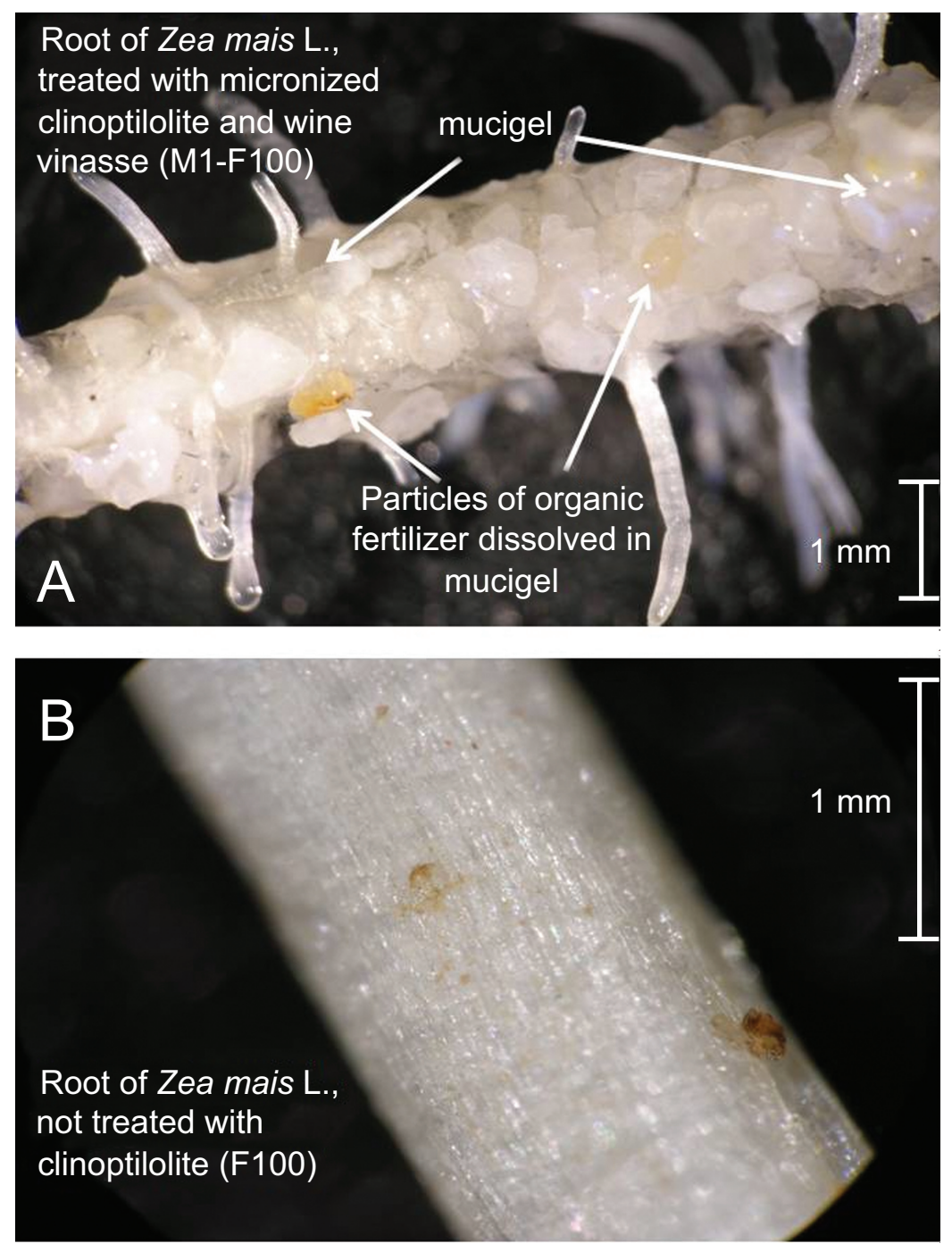

Fig. (3). Root of Zea mays L. treated with dried wine vinasse $\left(100 \mathrm{mg} \mathrm{L}_{\text {subst }}{ }^{-1}\right)$, in presence (A) or in absence (B) of clinoptilolite, after washing with distilled water. It is noticeable the "glue" effect of the mucigel (A) on quarz sand particles and its attitude to solubilize the water-soluble organic matter coming from the fertilizer. 

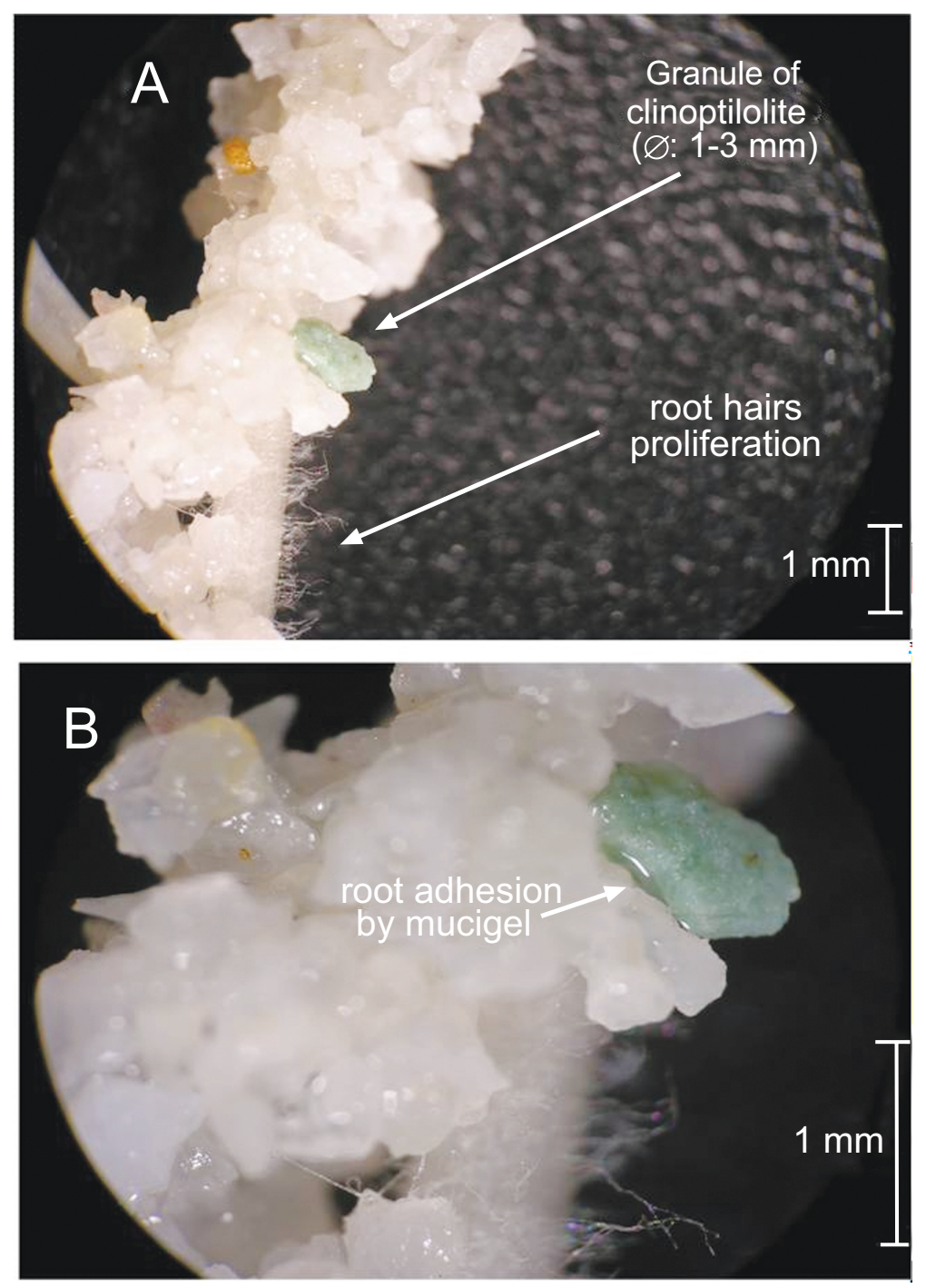

Fig. (4). Root hairs proliferation (A) of Zea mays L. in presence of granular clinoptilolite and adhesion of a granule of clinoptilolite on root surface by mucigel $(\mathbf{B})$.

was not solely linked to its physical impedance, but also to a specific synergic effect due to the organic fertiliser added to the growing medium.

The importance of the granular size of clinoptilolite in promoting roots growth is supported by the fact that micronized particles were more effective since the specific surface of these particles is much higher than that of granular zeolite [25] and, then, the amount of water that could be adsorbed on. The different particles size could differently interact with root surface, by changing the amount of produced mucilage and exudates [26], thus increasing the number of adventitious roots. Groleau-Renaud et al. [21] verified that maize roots growth was strongly influenced by mechanical impedance of the growing media and found a correlation between maize seedlings morphology and the amount of released carbon through root exudates. These findings suggested that root morphology is directly involved with the quality and the amount of root exudation. In our work, the amount of mucigel produced by root cells in correspondence to the contact point with the finest clinoptilolite particles seemed to increase and partially solubilize the organic fertiliser (Fig. 3-A), that could become more available for root absorption, particularly when little amount of micronized clinoptilolite was added.

As reported by Iijima et al. [27], mechanical impedance on plant growth generally determines not only changes in root morphology, but also a reduction of shoot matter. On the contrary, in our experience, since at the earlier stages of growth, micronized zeolite (M2) induced a significant increase in maize shoot length and weight, indicating a different mechanism of action. It could be hypothesized that this behaviour could be ascribed not properly to the impedance, but to the effect played by micronized particles of clinoptilolite in enhancing mucigel production that favours fertilizer solubilization, as confirmed by the positive influence of clinoptilolite in presence of wine vinasse on shoot parameters (see Fig. 2).

Different behaviour was observed for granular clinoptilolite: the shoot growth increase was less in growing media added with granular clinoptiololite with respect to that micronized one (M2): this suggested that mechanical impedance acted in a different way when bigger granules of zeolite were added, modifying root morphology, favouring mucigel 
production in root zones where granules adhered, but probably with a limited effect on inorganic fertilizer solubilization.

\section{CONCLUSIONS}

Results obtained with these short-term pot trials showed that clinoptilolite addition into the growing media had a positive effect on maize seedling growth. In particular, the treatment at $100 \mathrm{mg}$ of organic fertilizer $\times \mathrm{L}_{\text {subst }}{ }^{-1}$ and micronized clinoptilolite at $0.1 \% \mathrm{v} / \mathrm{v}$ strongly increased root weight. Besides, both the granular and micronized clinoptilolite favoured secondary roots and root hairs development, while the micronized one positively influenced maize shoot growth.

The positive effect of clinoptilolite on maize roots apparatus is expressed by increasing complexity of roots system, probably favouring root mucigel secretion, particularly in relation to the micronized zeolite. We advance the hypothesis that, in the portion of space close to the root surface, micronized granules of clinoptilolite are able to create a "micro-environment" in which excreted mucigel could solubilize the organic fertiliser, and consequently an increase of the nutrients availability. In this way, micronized clinoptilolite behaved as a sort of a "physical stimulant" for roots during seedling stage, promoting, as a consequence, maize shoot development.

Presented data should be considered as preliminary results. Probably, the positive effect of clinoptilolite on organic fertilisation of maize seedlings could be better expressed during the following stages of plant growth: this aspect should be taken into account for further investigation.

\section{REFERENCES}

[1] Anderson MW. Surface microscopy of porous materials. Curr Opin Solid State Mat Sci 2001; 5(5): 407-15.

[2] Barros MASD, Zola AS, Arroyo PA, Sousa-Aguiar EF, Tavares CRG. Binary ion exchange of metal ions in $\mathrm{Y}$ and $\mathrm{X}$ zeolites. Braz J Chem Eng 2003; 20(4): 413-21.

[3] Sersale R. Natural zeolites: processing, present and possible applications. Stud Surface Sci Catal 1985; 24: 503-12.

[4] Ramôa RF. Adaptation of the porosity of zeolites for shape selective reactions. Chem Mat Sci 1993; 22(1-2): 107-21.

[5] Valentukeviciene M. Removal of organic matter during groundwater treatment using powdered natural adsorbents (zeolites). Kavnas, Lithuania: Transactions of the Lithuanian University of Agriculture and Lithuanian Institute for Water Management 2002; vol. 18(40): pp. 1392-2335.

[6] Boettinger JL, Ming DW. Zeolites. Soil mineralogy with environmental applications. Soil Science Society of America, Madison, WI, USA: SSSA Book Series 2002; vol. 7(19): pp. 585-610.

[7] Emadi H, Nezhad JE, Pourbagher H. In vitro Comparison of zeolite (clinoptilolite) and activated carbon as ammonia absorbants in fish culture. In: Naga Y, Ed. Penang, Malaysia: The ICLARM Quarterly 2001; vol. 24(1-2), pp. 18-20.
[8] Mackown CT, Tucker TC. Ammonium nitrogen movement in a coarse-textured soil amended with zeolite. Soil Sci Soc Am J 1985; 49(2): 225-38.

[9] Ferguson GA, Pepper IL. Ammonium retention in sand amended with clinoptilolite. Soil Sci Soc Am J 1987; 51: 231-4.

[10] Ando H, Mihara C. The fate of ammonium nitrogen applied to flooded rice as affected by zeolite addition. Soil Sci 1996; 42: 5318.

[11] Ahmed OH, Aminuddin H, Husni MHA. Reducing ammonia loss from urea and improving soil-exchangeable ammonium retention through mixing triple superphosphate, humic acid and zeolite. Soil Use Manage 2006; 22(3): 315.

[12] Filcheva EG, Tsadilas CD. Influence of clinoptilolite and compost on soil properties. Commun Soil Sci Plant Anal 2001; 33(3-4): 595-607.

[13] Guo SS, Ai WD, Zhao CJ, Han LJ, Wang JX. Selection of rootzone media for higher plant cultivation in space. Space Med Eng 2004; 17(2): 93-7.

[14] Ferguson GA, Pepper IL, Kneebone WR. Growth of creeping bentgrass on a new medium for turfgrass growth: clinoptilolite zeoliteamended sand. Agron J 1986; 78: 1095-8.

[15] Barbarick L, Lai TM, Eberl DD. Exchange fertilizer (phosphate rock plus ammonium-zeolite) effects on sorghum-sudangrass. Soil Sci Soc Am J 1990; 54: 911-6.

[16] Ming DW, Gruener JW, Henderson KE, Barta DJ, Galindo CJr. Production of fresh vegetable crops in zeoponic substrates: preliminary results. Paper presented at the Annual Meeting of ASGSB 2001; p. 99.

[17] Li D, Joo JK, Christians NE, Minner DD. Inorganic soil amendment effects on sand-based sports turf media. Crop Sci 2000; 40: 1121-5.

[18] Al-Busaidi A, Yamamoto T, Inoue M, Eneji AE, Mori Y, Irshad M. Effects of zeolite on soil nutrients and growth of barley following irrigation with saline water. J Plant Nutr 2008; 31(7): 1159-73.

[19] Ayan S, Yahyaoglu Z, Gerçek V, Şahin A. Utilization of zeolite as a substrate for containerized oriental spruce (Picea orientalis L.) seedlings propagation. Acta Horticult 2006; 779: 583-90.

[20] Ayan S, Tillki F. Morphological attributes of oriental spruce (Picea orientalis (L.) Link.) seedlings grown in peat-based amended with natural zeolite. Acta Agr Hung 2007; 55: 363-73.

[21] Groleau-Renaud V, Plantureux S, Guckert A. Influence of plant morphology on root exudation of maize subjected to mechanical impedance in hydroponic conditions. Plant Soil 1998 ; 201: 231-9.

[22] Boeuf-Tremblay V, Plantureux S, Guckert A. Influence of mechanical impedance on root exudation of maize seedlings at two development stages. Plant Soil 1995; 172: 279-87.

[23] Gül A, Eroğul D, Öztan F, Tepecik M. Effect of growing media on plant growth and nutrient status of crisp-head lettuce. Acta Horticult 2004; 729-730.

[24] Veen BW, Boone FR. The influence of mechanical resistance and soil water on growth of seminal roots of maize. Soil Tillage Res 1990; 16: 219-26.

[25] Davis MC. Characterisation of divery systems, XPS, SIMS, and AFM analysis. In: Wiley A, Ed. Encyclopaedia of Controlled drug delivery. San Francisco, USA: John Wiley \& Sons 1999; pp. 26975.

[26] Pinton R, Varanini Z, Nannipieri P. Eds. The rhizosphere. Boca Raton, London, New York: Taylor \& Francis Group, CRC Press 2007.

[27] Iijima M, Kono Y, Yamauchi A, Pardales JR. Effect of soil compaction on the development of rice and maize root systems. Environ Exp Bot 1991; 31: 333-42. 